\title{
AFE \\ Microstructure, SDAS and Mechanical Properties of A356 alloy Castings Made in Sand and Granulated Blast Furnace Slag Moulds
}

\author{
B.R. Jinugu*, N.M. Inampudi \\ Department of Metallurgical Engineering, Andhra University, Visakhapatnam - 530003, India \\ *Corresponding author. E-mail address: baburaojinugu@yahoo.com
}

Received 01.12.2016; accepted in revised form 19.01.2017

\begin{abstract}
Investigations were carried out to ensure the granulated blast furnace (GBF) slag as an alternative mould material in foundry industry by assessing the cast products structure property correlations. Sodium silicate- $\mathrm{CO}_{2}$ process was adopted for preparing the moulds. Three types of moulds were made with slag, silica sand individually and combination of these two with $10 \%$ sodium silicate and 20 seconds $\mathrm{CO}_{2}$ gassing time. A356 alloy castings were performed on these newly developed slag moulds. The cast products were investigated for its metallography and mechanical properties. Results reveal that cast products with good surface finish and without any defects were produced. Faster heat transfers in slag moulds enabled the cast products with fine and refined grain structured; and also, lower Secondary Dendrite Arm Spacing (SDAS) values were observed than sand mould. Slag mould casting shows improved mechanical properties like hardness, compression, tensile and impact strength compared to sand mould castings. Two types of tensile fracture modes, namely cleavage pattern with flat surfaces representing Al-Si eutectic zone and the areas of broken Fe-rich intermetallic compounds which appear as flower-like morphology was observed in sand mould castings. In contrast, GBF slag mould castings exhibit majority in dimple fracture morphology with traces of cleavage fracture. Charpy impact fractured surfaces of sand mould castings shows both transgranular and intergranular fracture modes. Only intergranular fracture mode was noticed in both GBF slag and mixed mould castings.
\end{abstract}

Keywords: Silica sand; GBF slag; $\mathrm{CO}_{2}$ process; A 356 alloy castings; SEM-EDX; Mechanical properties

\section{Introduction}

Silica sand is traditionally used in the foundry applications as a moulding material. Due to the depletion of natural materials, there is a need to find suitable alternative material, which will replace the conventional materials. The large-scale industrialization has resulted accumulation of huge amount of industrial wastes, endangering the environment in terms of land, air and water pollution. In order to use the industrial waste in huge quantities efforts are being made to use the same as a substitute of natural resources. Various efforts have been made to use industrial solid wastes like fly ash, red mud, blast furnace slag etc. in civil and construction works. In view of the large quantity of granulated blast furnace (GBF) slag availability, having similar physical and chemical properties with silica sand and limited literature on GBF slag usage in foundry industry attempts are made to address the same. Present investigations were carried out to ensure the granulated blast furnace (GBF) slag as an alternative 
mould material in foundry industry by assessing the cast products structure property correlations. Hence, investigation was performed on A356 (Al-7.5\% Si) alloy castings in sand, GBF slag and combinations of these two moulds; and same castings were characterized for its microstructure and mechanical properties. Owing to the superiority, sodium silicate $-\mathrm{CO}_{2}$ process was adopted for all the moulds preparation $[1,2]$. The obtained results may be useful for ensuring GBF slag as an alternative mould material in non-ferrous foundries.

\section{Materials and methods}

In the present investigation two types of materials namely high silica sand and granulated blast furnace (GBF) slag was chosen. Silica sand is the principle moulding sand used in foundry industries. It was procured from Chirala, Andhra Pradesh, India. Blast furnace slag in granulated form procured from Visakhapatnam Steel Plant, Visakhapatnam, India. Preheating of the silica sand and granulated blast furnace slag (GBF) particulates were carried out in a muffle furnace at $300^{\circ} \mathrm{C}$ for 3 hours to get rid of the any moisture presence in them. Investigations on their chemical, physical and moulding properties were reported in earlier works [3].

\subsection{Melting and casting practice}

Al-Si alloy having a wide range of applications in the automotive and aerospace, also provides the most significant part of all shaped castings manufactured. Hence, melting and casting practice of A $356(\mathrm{Al}-7.5 \% \mathrm{Si})$ alloy castings was performed on these newly made GBF slag moulds. For this study three types of moulds were selected, namely; Type 1: $100 \%$ Silica sand; Type 2: $100 \%$ GBF slag; and Type 3: mixture of $50 \%$ GBF slag $+50 \%$ Sand. The optimum mould properties were obtained by addition of $10 \%$ sodium silicate along with a $\mathrm{CO}_{2}$ gassing of $15-20$ seconds' duration [4]. This work is first of its kind; hence, only regular shaped cylindrical castings $(18$ X $180 \mathrm{~mm}$ diameter and length respectively) are aimed to cast. Cope and drag as well as split pattern was used for preparing the mould with mould cavity. A356 alloy ingots of 500 grams in weight was taken in a graphite crucible and melted separately in a calibrated high temperature melting furnace at $750{ }^{\circ} \mathrm{C}$. The molten metal was allowed to fill in the mould cavities via sprue, runner and in gates; care was taken to ensure continuous and smooth flow of the liquid metal while filling in the mould cavities. Riser was placed in the mould to ensure complete mould cavity filling. After cooling the castings were withdrawn from mould boxes and same was undergone for further metallographic and mechanical properties evaluation. Figure 1 shows the finished A356 alloy cylindrical castings before and after machining.

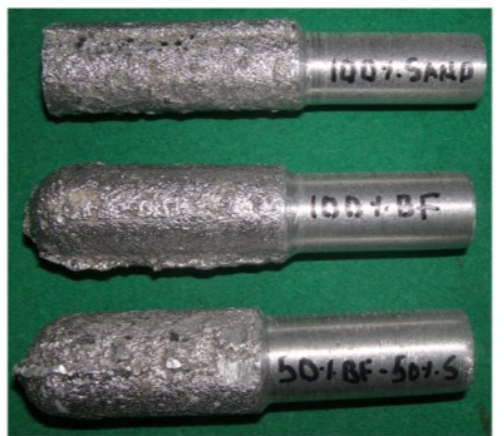

Fig. 1. A 356 alloy finished cylindrical castings before and after machining

\subsection{Metallographic evaluation - SEM-EDS analysis}

Scanning Electron Microscope with Energy Dispersive spectrum analysis was carried out to assess the morphological changes and the elemental analysis on castings made through sand, slag and mixed moulds. The analysis was carried out using Scanning Electron Microscope (SEM) fitted with ED's spectrum (Model: JEOL-JSM-6480 LV). Secondary Dendrite Arm Spacing (SDAS) measurements were carried out on all the samples. Image $\mathrm{J}$ software was used to evaluate the same.

\subsection{Mechanical properties evaluation}

\subsubsection{Hardness studies}

Rockwell hardness tests were carried out on these cast samples to have comparative strength properties of the slag and sand castings. Standard testing procedure was followed by applying the minor load of $10 \mathrm{kgf}$; and major load of $100 \mathrm{kgf}$ with HRB scale. The hardness survey was done across the longitudinal and transverse directions of the samples. Also, hardness was measured at four different diagonals of the specimen and averaged. An average of eight readings was considered to report the respective hardness value.

\subsubsection{Tensile testing}

Tensile specimens were casted directly from respective slag, sand and combination of sand and slag moulds. Melting and casting procedure to make these tensile specimens was followed the same procedure as discussed in section 2.1. Figure 2 show the standard tensile test specimen and its experimental set up respectively. Tensile strength of materials under investigation was determined by using calibrated computer controlled servo hydraulic universal testing machine (model: Fuel Instruments and Engineers (FIE -UTE 100 with 1000 tons' capacity). The test was conducted at a constant cross head speed of $0.5 \mathrm{~mm} / \mathrm{min}$. The testing procedure was followed as per ASTM E-8 standards. Online plotting of load versus extension has done continuously though a data acquisition system. Figure 3 shows the A356 alloy tensile specimens before and after testing of sand, slag and mixture of these two castings respectively. 


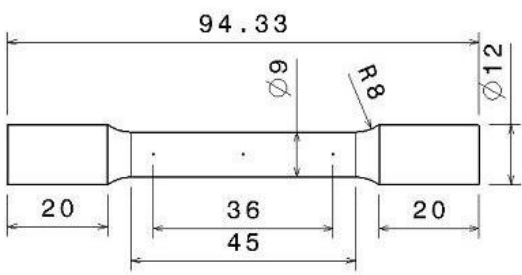

(a)

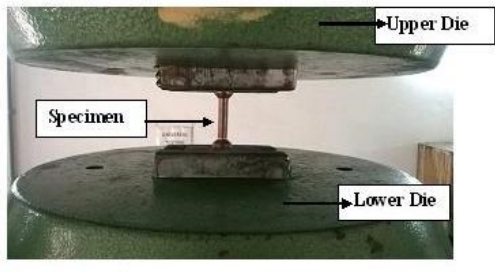

Fig. 2. (a) Standard tensile specimen (b) Closer view of the tensile testing

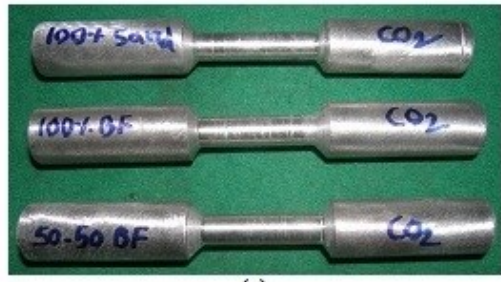

(a)

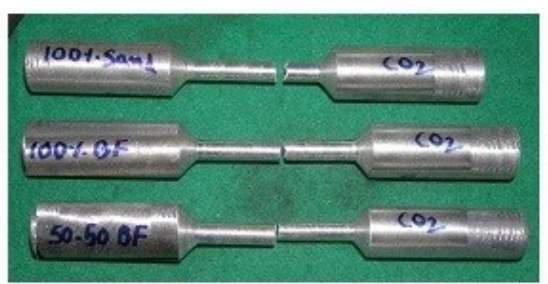

(b)

Fig. 3. Tensile specimens: (a) before testing (b) after testing

\subsubsection{Compression testing}

Standard cylindrical specimens with aspect ratio $(\mathrm{H} / \mathrm{D}=1.0)$ of $16 \mathrm{~mm}$ length and $16 \mathrm{~mm}$ diameter were machined from the cylindrical finger castings of respective materials. Sample edges were chamfered to minimize the folding. Concentric grooves of $0.5 \mathrm{~mm}$ depth were made on both the end surfaces of the sample. These samples were compressed by placing between the flat platens at a constant cross head speed of $0.5 \mathrm{~mm} / \mathrm{min}$ in dry condition, using a calibrated computer controlled servo hydraulic 1000T universal testing machine (Model: FIE-UTE). Cold work die steel dies (flat flattens) were machined to produce smooth finish to yield low friction. Figure 4 shows the cylindrical samples of A356 alloy before and after deformation respectively. Online plotting of load versus displacement has done continuously through a data acquisition system.

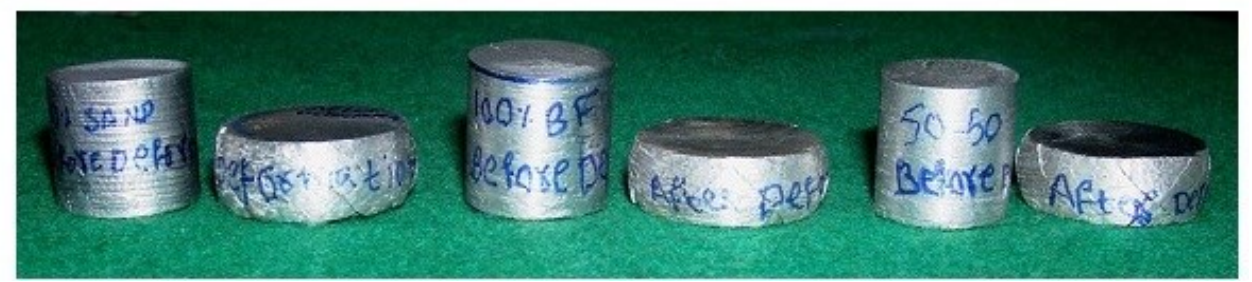

Fig. 4. Cylindrical samples with aspect ratio $=1.0$ showing bulge profiles before and after deformation under compression

\subsubsection{Charpy Impact testing}

Charpy impact tests were carried out on these cast samples to have comparative impact properties of the slag and sand castings. The V-notched impact test standard specimens with dimensions of 10 X 10 X $55 \mathrm{~mm}$ were made per ASTM-A370. The test was conducted at room temperature and was repeated for three times

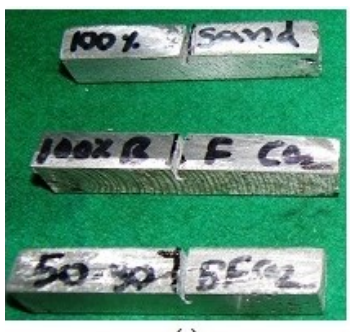

(a) of each material. An average of three readings was considered to report the respective impact value. The Charpy impact test machine (Model: R17 DT 63M4: Micro technology, Chennai, India) with calibrated was chosen for above test. Figure 5 shows the A356 alloy Charpy impact specimens before after testing.

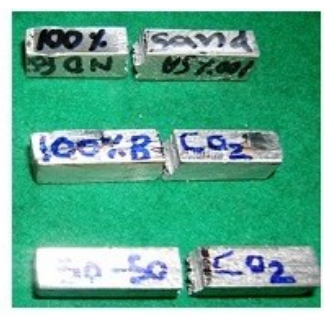

Fig. 5. Charpy impact specimens: (a) before testing (b) after testing 


\section{Results and discussion}

\subsection{A356 alloy laboratory castings - mould heat transfer rates}

The cylindrical finger castings after cooling were examined and revealed that very less amount of mould ingredients were stick to the casting surfaces; further slag castings show cleaned surface finish on par with sand castings. All the castings show good surface finish with no surface defects; it also reveals good dimensional accuracy. Before and after machined cylindrical castings shows no porosity or other surface defects presence in any of the either sand or slag mould castings.

Mould heat transfer rate plays a significant role in obtaining final microstructure and its corresponding mechanical properties of the castings [5-12]. Studies were performed to evaluate the

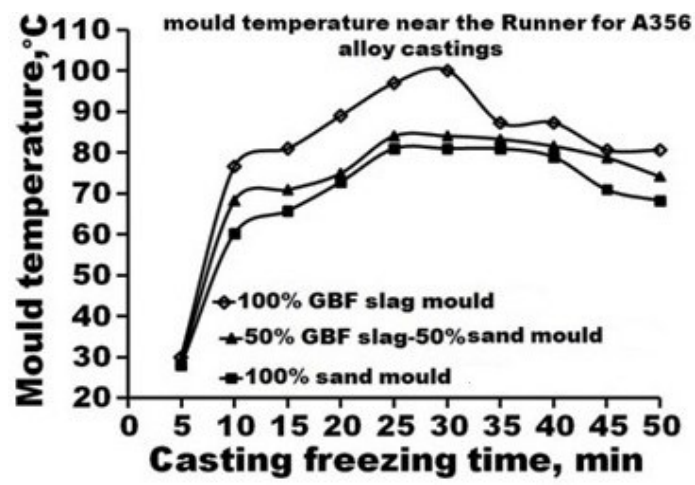

(a) mould heat transfer rates of slag, sand and mixture of these two moulds. The same was measured by observing the mould temperature at three locations namely near the runner, riser and mid-way of the mould cavity with solidification times. This assessment was done separately for all the three types of moulds; the obtained results were shown in figure $6(\mathrm{a}-\mathrm{c})$. These figures reveal that initial solidification period (up to 30 minutes' duration) increase in mould temperature was noticed then slowly lowering the mould temperature; the same trend was observed for all the three moulds. At any given freezing time GBF slag mould shows more mould temperature, then mixture of sand-slag mould and finally sand moulds. This was true for all the three locations namely runner, riser and mould mid way. From these results, it can conclude that GBF slag moulds facilitate faster heat transfer rates than sand moulds; hence faster solidification rates of the castings.

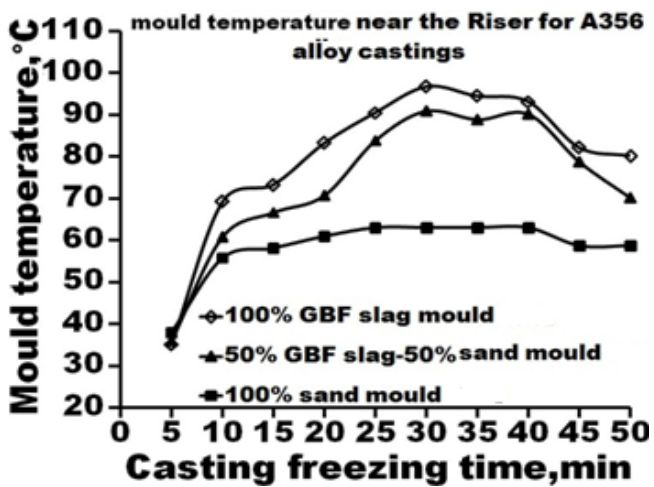

(b)

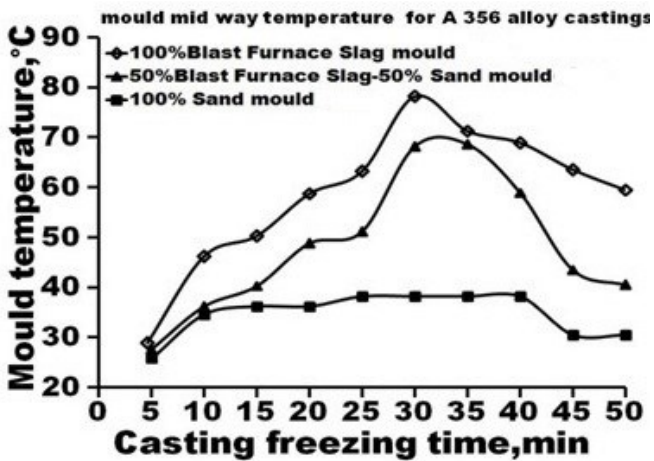

(c)

Fig. 6. Variation in mould temperatures at various locations during freezing of A356 alloy castings for Sand, GBF slag and mixture of these two moulds: (a) near the Runner (b) near the Riser, and (c) Midway of the mould

\subsection{Microstructure evaluation}

Figure 7(a-c) indicate the SEM micrographs of A356 alloy castings made in sand, GBF slag and mixture of these two moulds respectively. A356 aluminium alloy is a hypo eutectic alloy (Al$7.5 \% \mathrm{Si})$; microstructure mainly consists of soft \& ductile $\alpha$ aluminum dendrite phase containing magnesium and silicon in solution and hard \& brittle eutectic phase $(\alpha-\mathrm{Al}+\mathrm{Si})$ in the interdendrite region, as shown in figures $7(\mathrm{a}-\mathrm{c})$. The fine and refined grain structure was obtained for GBF slag mould samples than sand mould, figure7 (b); this might be due to the faster solidification rates in these slag moulds. Microstructure of mixed mould casting shows in between the sand and slag castings. In general, the rate at which a casting cools affects its microstructure, quality and properties. The sand mould casting process cool slowly compare to either metallic or chromite sand moulds. This slow cooling increases the metal's grain size, creating a coarse microstructure; coarse grain structure weakens 
the casting [13-16]. The same phenomenon was noticed in the present investigation. Conversely, the slag mould process can cool

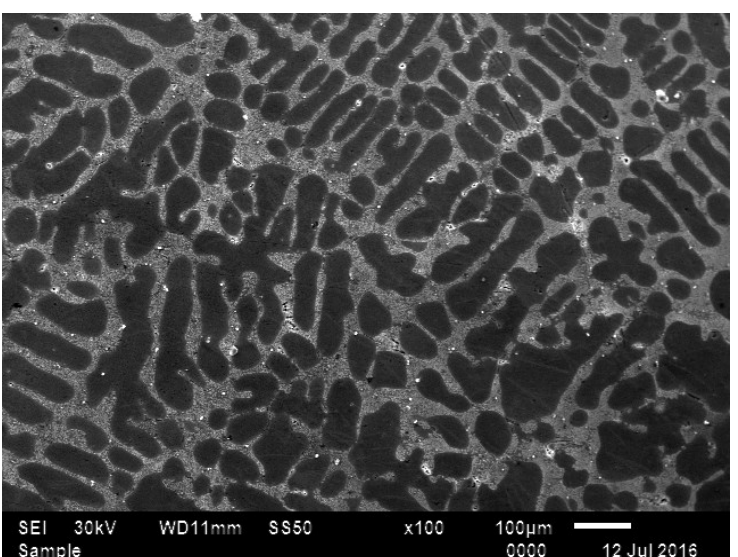

(a) more quickly, resulting microstructure with small size grains.

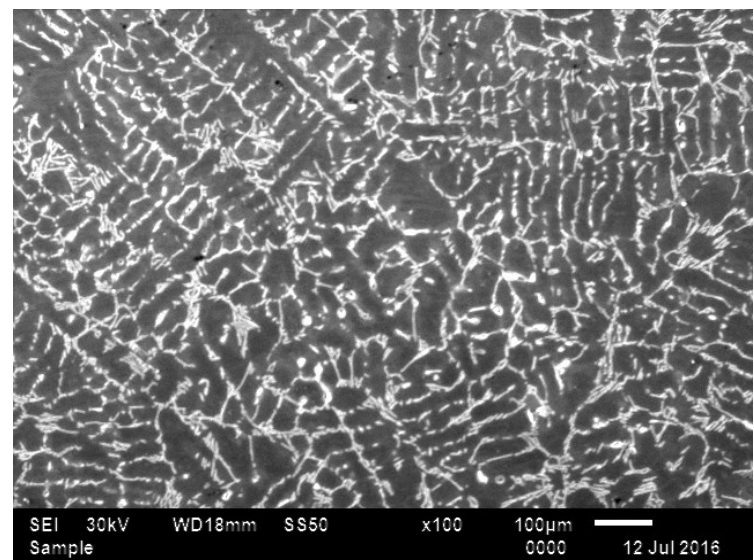

(b)

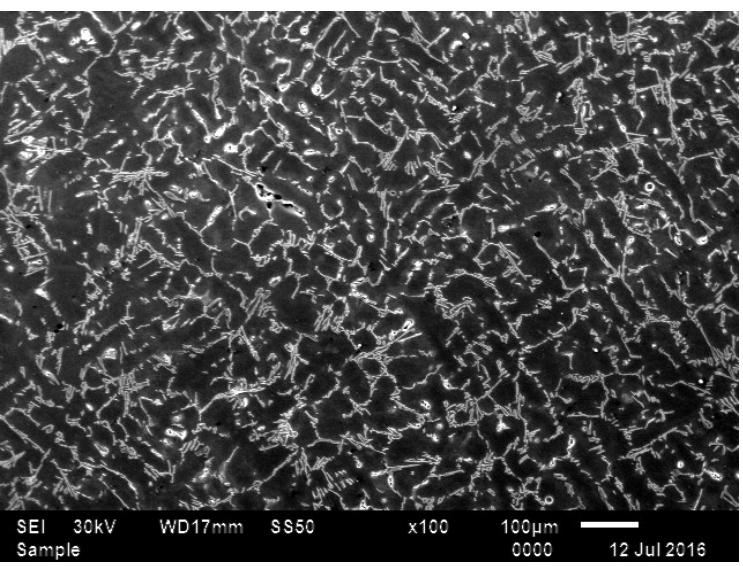

(c)

Fig. 7. SEM micrographs of A356 alloy castings: (a) Silica sand mould (b) GBF Slag mould and (c) Mixture of 50\% GBF slag and 50\% Silica sand mould.

As cast microstructures were analyzed for its Secondary Dendrite Arm Spacing (SDAS) values by using Simagis microstructure image software. The linear line intercept method was used to measure the dendrite arm spacing with different orientations at different locations $[17,18]$. Each micrograph was divided into three locations, namely location 1,2 and 3. A line along the dendrite arm is drawn and the number of arms crossing this line was then counted. Figure 8 (a-c) shows the typical A356 alloy microstructures with line drawn for measurement of SDAS of silica sand, GBF Slag and mixture of these two moulds respectively. The results from SDAS measurements were shown in table 1; average SDAS values of silica sand, GBF Slag and mixture of these two moulds were $42 \mu \mathrm{m}, 31 \mu \mathrm{m}$ and $38 \mu \mathrm{m}$ respectively. GBF slag mould castings show lower SDAS values due to the fast mould cooling rates than either silica sand or mixed mould. 


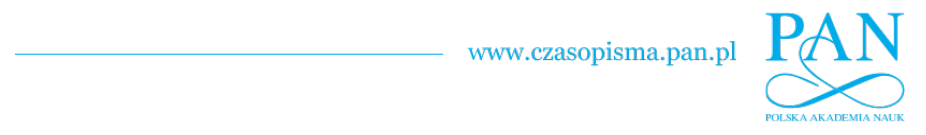

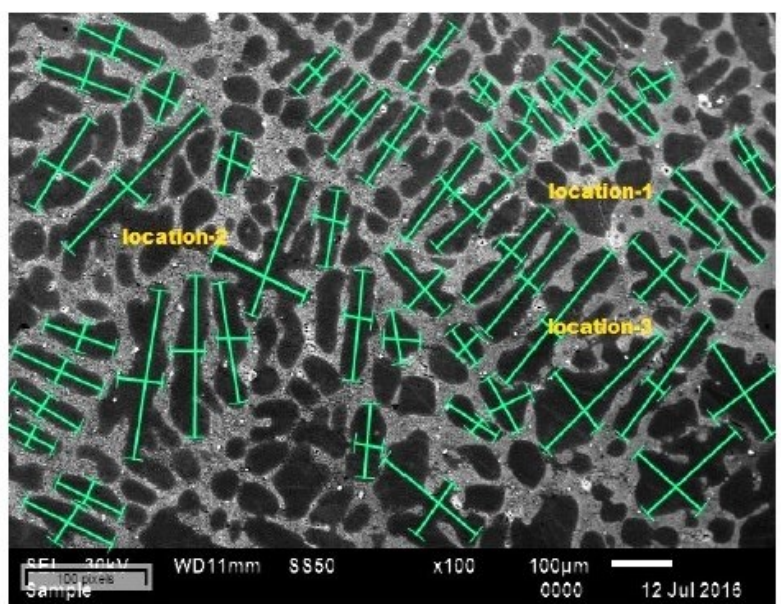

(a)

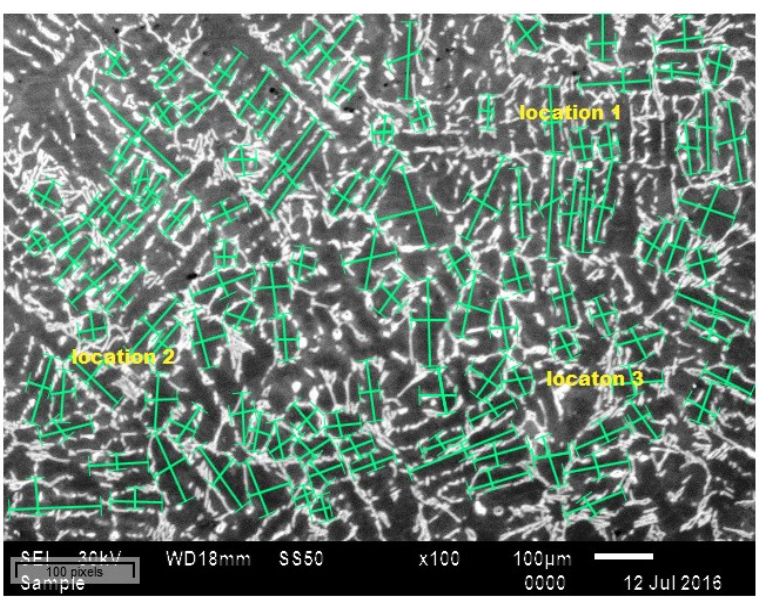

(b)

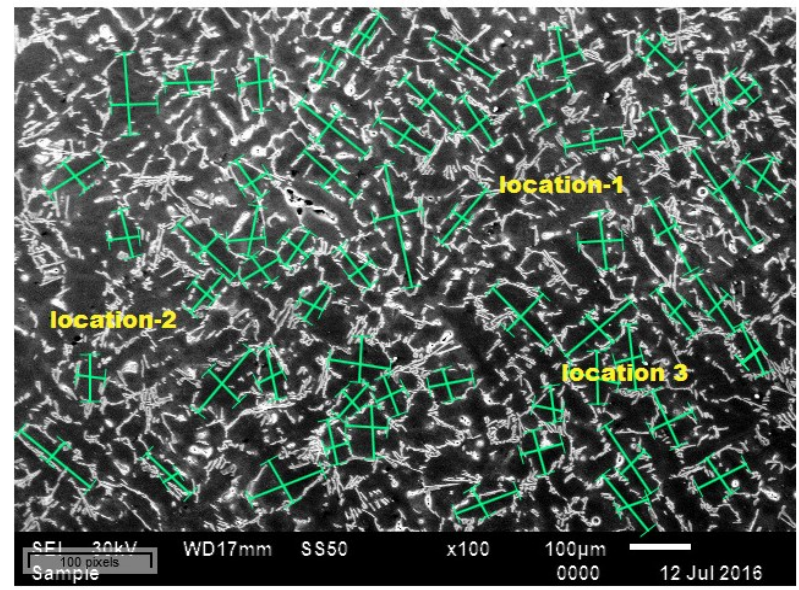

(c)

Fig. 8. SEM micrographs for secondary dendrite arm spacing (SDAS) measurements at different locations of A356 alloy castings: (a) silica sand mould (b) GBF slag mould and (c) Mixture of 50\% GBF slag and 50\% silica sand mould.

Table 1.

Measured values of Secondary Dendrite Arm Spacing (SDAS)

Secondary dendrite arm spacing, (SDAS), $\mu \mathrm{m}$

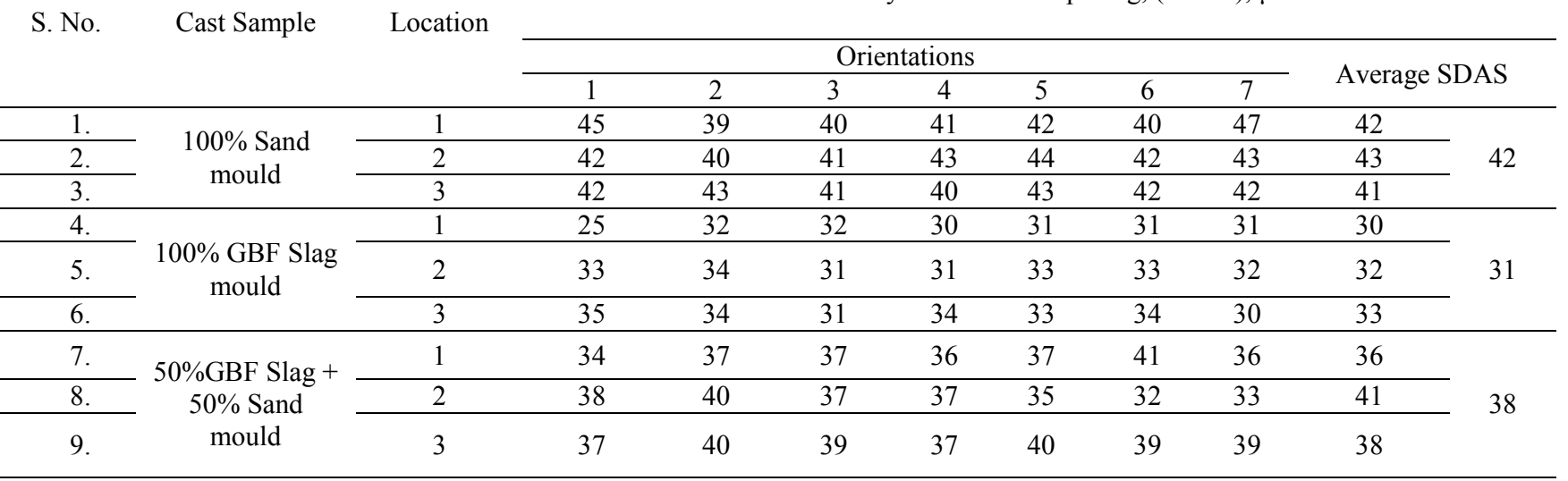




\subsection{Hardness survey}

Figure 9(a-c) shows the hardness profiles of A356 alloy castings made by sand, GBF slag and mixture of slag and sand moulds respectively. The obtained hardness (HRB scale) values were like the available literature [19]. Consistent and uniform hardness was observed throughout the cross section of the sample; this was true for all the castings under investigation. However, sand casting shows lower hardness compared to slag castings. Enhanced hardness in slag castings might be due to the presence of fine grained microstructure consists of $\alpha-\mathrm{Al}$ dendrites and hard $\&$ brittle eutectic phase $(\alpha-\mathrm{Al}+\mathrm{Si})$. In case of mixed mould castings hardness was in between the slag and sand mould castings.

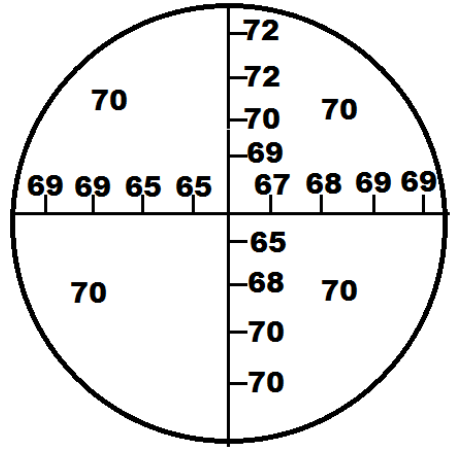

(a)

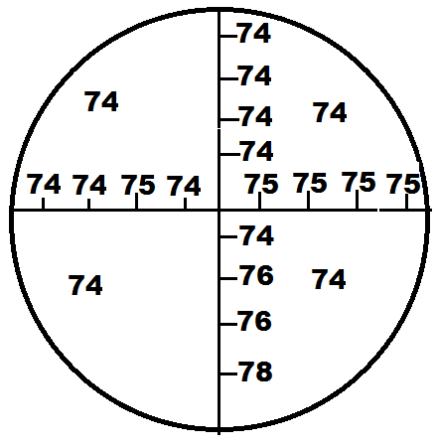

(b)

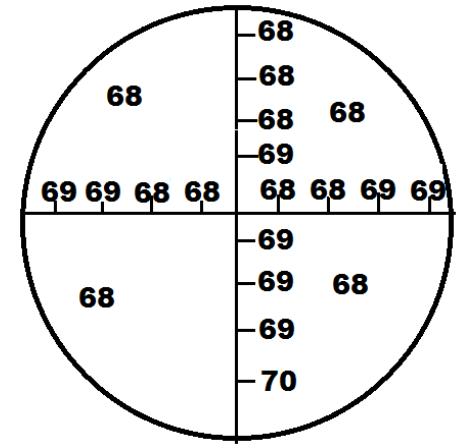

(c)

Fig. 9. Hardness (HRB) profile of A356 aluminium alloy castings along the cross section of the sample: (a) 100\% Silica Sand (b) 100\% GBF Slag and (c) Mixture of 50\% GBF slag and 50\% Silica sand

\subsection{Compression and tensile properties}

Compression and tensile properties of A356 alloy made through sand, slag and mixture of these two moulds was studied. The obtained results were shown in figure 10 and 11 for compression and tensile properties respectively. The load requirement increased with increase in deformation for the material under investigation. The slag mould castings show higher loads with slightly improved amount of deformation than the sand moulds. This might be due to slag moulds enable to have faster

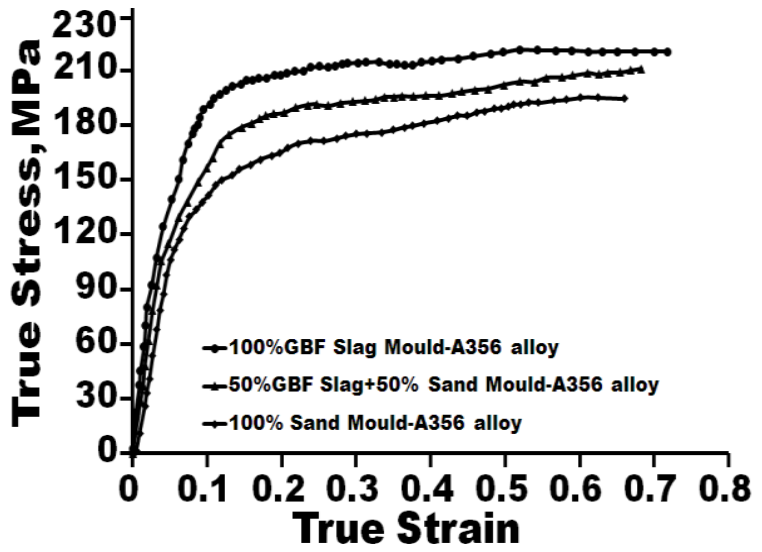

Fig. 10. Compression properties of A356 alloy made in sand, GBF slag and mixture of these two moulds (aspect ratio $(\mathrm{H} / \mathrm{D})=1.0)$

Further SEM studies on tensile fractured specimens were evaluated and same shown in figure 12 (a-c) for sand, slag and combinations of these two moulds castings respectively. A 356 cooling rates and lead to a fine grain structure than castings made in sand moulds. Whereas mixed mould castings exhibit the properties in between sand and slag mould castings. Grain size has a significant effect on strength of the metals. As the grain size decreases the strength and ductility of metal increase, micro porosity in the casting decreases and the tendency for the casting to crack during solidification decreases. The strength of the materials is expected to increase by the presence of fine grain structure due to the strengthening effects occurred in combination of both grain boundary and strain hardening mechanisms [20].

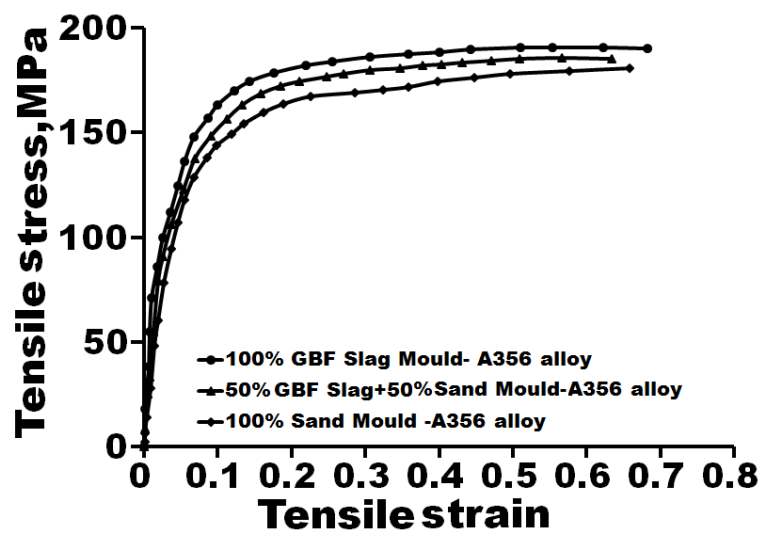

Fig. 11. Tensile properties of A356 alloy made in sand, GBF slag and mixture of these two moulds

alloy casted in $100 \%$ sand mould shows two types of fracture characteristics, as shown in figure 12 (a). The areas labeled as ' $C$ ' show a cleavage pattern with flat surfaces representing $\mathrm{Al}-\mathrm{Si}$ 
eutectic zone. In these flat areas, the Si platelet might be torn off from the $\mathrm{Al}$ matrix, leaving a terrace with a smooth surface. These faces were more probably formed because of fracture of brittle $\mathrm{Si}$ phase crystals [21]. In the present investigation of sand mould castings, larger Secondary Dendrite Arm Spacing (SDAS) and elongated eutectic silicon particles were observed. Generally elongated eutectic silicon particles fracture more frequently than the spherical silicon particles since they are the main sources of stress concentration [22]. The micrograph (figure 12 (a)) also shows the areas of broken Fe-rich intermetallic compounds, labeled as ' $B$ '. These areas appear as flower-like morphology with no evident cleavage faces. The existence of these areas might be due to severe breakup occurred at these intermetallic areas [23]. In general, intermetallics have poor deformation properties; during crack propagation the stress field of the main crack broke the intermetallics only without destroying the boundaries among the intermetallic particles or the boundaries between the intermetallic phases and the $\mathrm{Al}-\mathrm{Si}$ eutectic [24].

In contrast, SEM micrographs of A356 alloy tensile fractured samples obtained by $100 \%$ GBF slag mould exhibit majority in dimple fracture morphology with traces of cleavage fracture. These dimples were deep and distributed uniformly, as shown in figure 12(b). The smaller SDAS and finer eutectic silicon particles in this casted sample make the grain cell boundaries more discontinuous. Therefore, a stronger interaction between slip bands and plastic flow generates in the grain boundaries [25, 26]. The cracking of eutectic silicon particles takes place in the grain boundaries, and the final fracture path tends to pass through the eutectic phase along the grain boundaries of the $\alpha$-Al primary phase. As a result, the fracture generates mostly by dimple rupture with cracked eutectic silicon particles, and exhibits an intergranular fracture mode, lead to the optimum mechanical properties [27]. In case of mixed mould cast product, fracture behavior reveal the mixed quasi-cleavage type morphology. Here the dimples were flat and distributed non-uniformly, as shown in figure 12 (c). Figure 13 (a-c) shows the EDS of tensile fracture surfaces of A356 alloy made by various moulds of sand, GBF slag and mixture of sand and slag. It was clearly evident that presence of Fe-rich intermetallics in the alloy morphology.

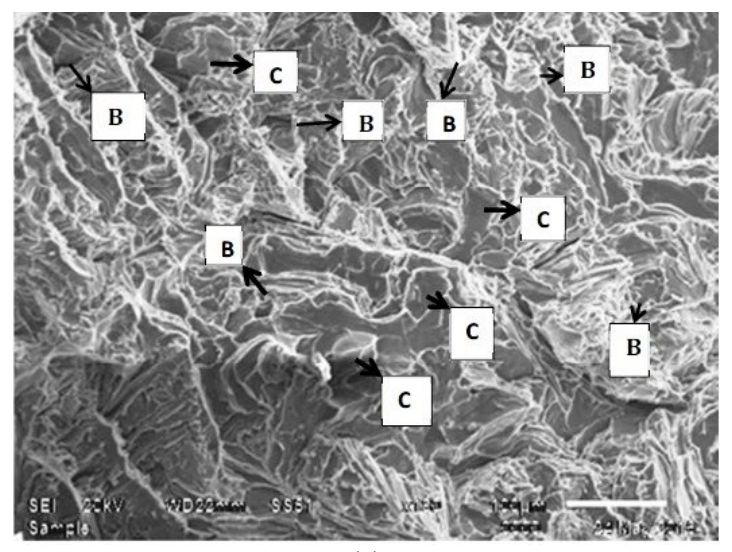

(a)

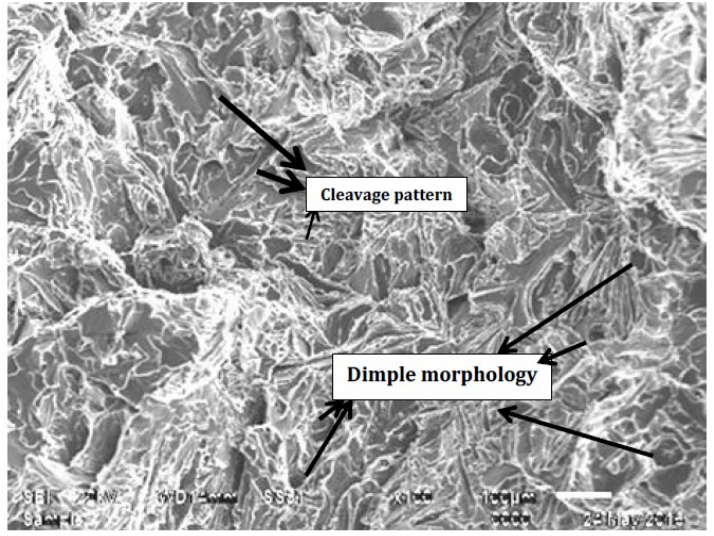

(b)

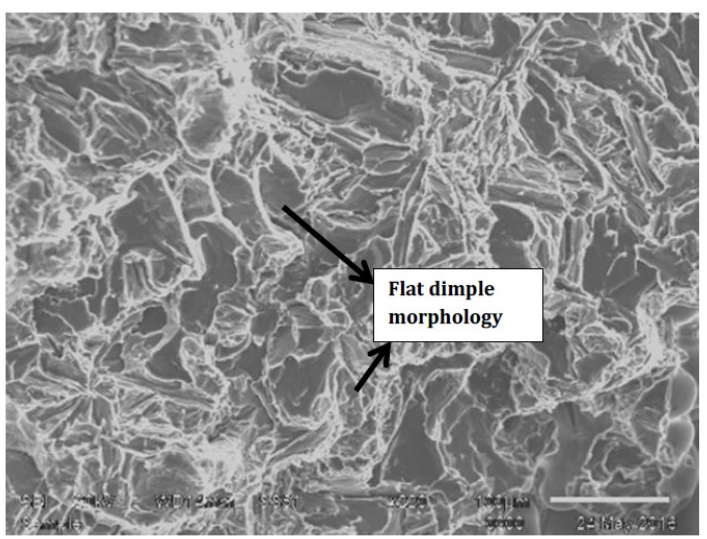

(c)

Fig. 12. SEM micrographs for tensile fractured surfaces of A356 alloy castings by various moulds: (a) $100 \%$ Sand (b) $100 \%$ GBF slag and (c) combinations of these two moulds. 


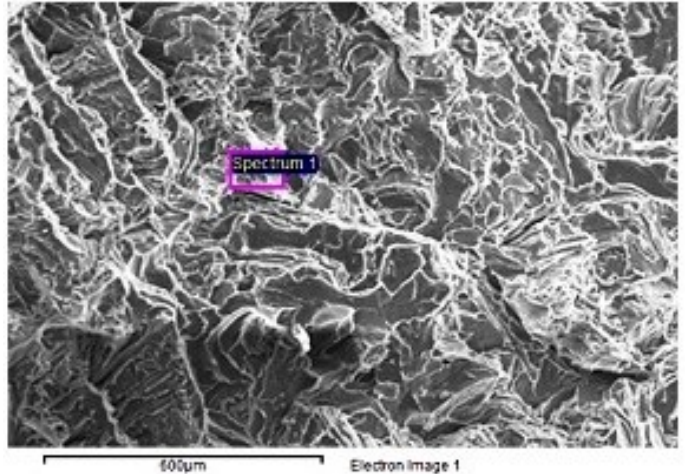

(a)

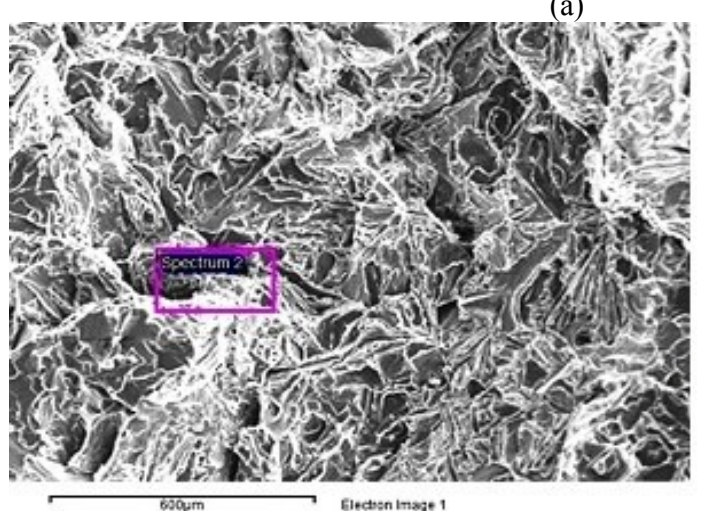

(b)

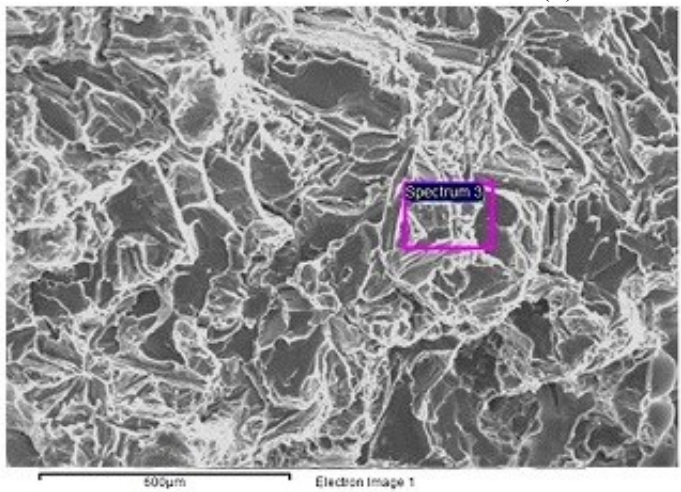

(c)
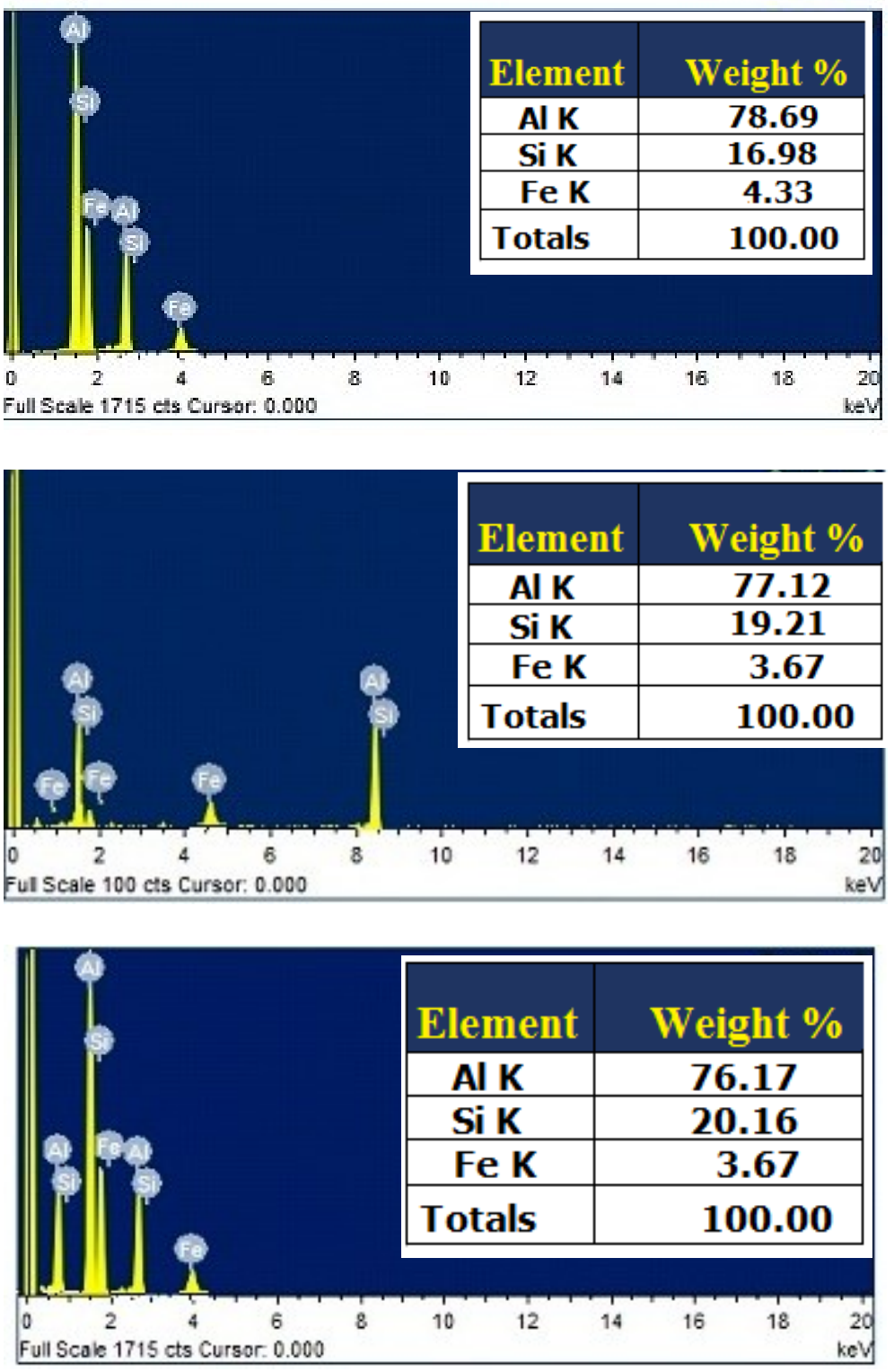

Full Scale 1715 cts Cursor. 0.000

Fig. 13. EDS of tensile fracture surfaces of A356 alloy made by various moulds: (a) $100 \%$ Sand (b) $100 \%$ GBF Slag (c) Mixture of Sand and Slag

\subsection{Charpy impact properties}

In case of impact strength, GBF slag castings shows similar results with silica sand castings. The summary of the obtained A356 alloy mechanical properties for all the moulds under investigation was shown in table 2. SEM studies on charpy impact fractured specimens were evaluated and same shown in figure $14(\mathrm{a}-\mathrm{c})$ for sand, slag and combinations of these two moulds castings respectively. The $100 \%$ sand mould castings shows both transgranular and intergranular fracture modes, however majority of the areas shows transgranular fracture mode, as shown in figure 14(a). The fracture profile follows a preferential path through the eutectic phase, and in many cases, it also follows through a secondary dendrite arm. In general fracture development involves the cracking of $\mathrm{Si}$ particles. Once the particle cracks, a micro void is formed and tends to grow. This particle cracking process continues until a critical volume fraction of cracked particles is reached. Eventually, the alloy fails because of a rapid linking process among micro cracks. This linking process depends on the size of the Secondary Dendrite Arm Spacing (SDAS). When SDAS is large, this linkage is transgranular, whereas in small SDAS it becomes intergranular 
[28-31]. In this present investigation, larger SDAS values were observed for sand mould castings; hence majority of the transgranular fracture was noticed. However, smaller SDAS were reported in GBF slag and mixed mould castings, hence only intergranular fracture mode was noticed on these samples, as shown in figure 14 (b \& c). Figure 15 (a-c) shows EDS of intermetallic compounds on the impact fracture surface of A356 alloy made by various moulds of sand GBF slag and combinations of these two moulds respectively.

Table 2.

Mechanical properties of A356 alloy made through sand, slag and combination of these two moulds after compression, tensile and impact testing

\begin{tabular}{|c|c|c|c|c|c|c|c|c|c|c|}
\hline \multirow{2}{*}{$\begin{array}{l}\text { S. } \\
\text { No. }\end{array}$} & \multirow{2}{*}{ Material } & \multirow{2}{*}{ Mould material } & \multirow{2}{*}{ Hardness } & \multicolumn{4}{|c|}{ Tensile properties } & \multicolumn{2}{|c|}{ Compression properties } & \multirow{2}{*}{$\begin{array}{l}\text { Impact } \\
\text { strength } \\
\text { (joules) }\end{array}$} \\
\hline & & & & $\begin{array}{c}\text { Y.S } \\
(\mathrm{MPa})\end{array}$ & $\begin{array}{c}\text { UTS } \\
(\mathrm{MPa})\end{array}$ & $\begin{array}{l}\text { break } \\
\text { stress } \\
(\mathrm{MPa})\end{array}$ & $\begin{array}{c}\% \\
\text { Elongatio } \\
\mathrm{n}\end{array}$ & $\begin{array}{c}\text { UTS } \\
(\mathrm{MPa})\end{array}$ & $\begin{array}{l}\text { break stress } \\
\quad(\mathrm{MPa})\end{array}$ & \\
\hline \multirow{3}{*}{1} & \multirow{3}{*}{$\begin{array}{l}\text { A356 } \\
\text { alloy }\end{array}$} & $100 \%$ Sand & $62 \mathrm{HRB}$ & 178 & 183 & 183 & 1.21 & 195 & 194 & 6.0 \\
\hline & & $100 \%$ GBF Slag & $75 \mathrm{HRB}$ & 187 & 190 & 188 & 1.21 & 220 & 215 & 6.2 \\
\hline & & $\begin{array}{l}50 \% \text { GBF Slag } \\
+50 \% \text { Sand }\end{array}$ & $68 \mathrm{HRB}$ & 182 & 185 & 183 & 1.20 & 210 & 196 & 6.0 \\
\hline
\end{tabular}

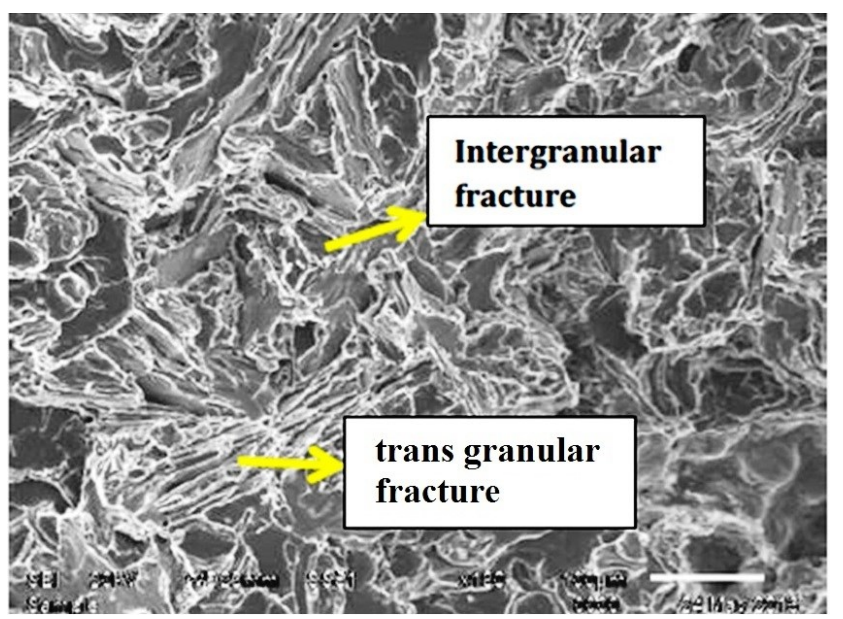

(a)

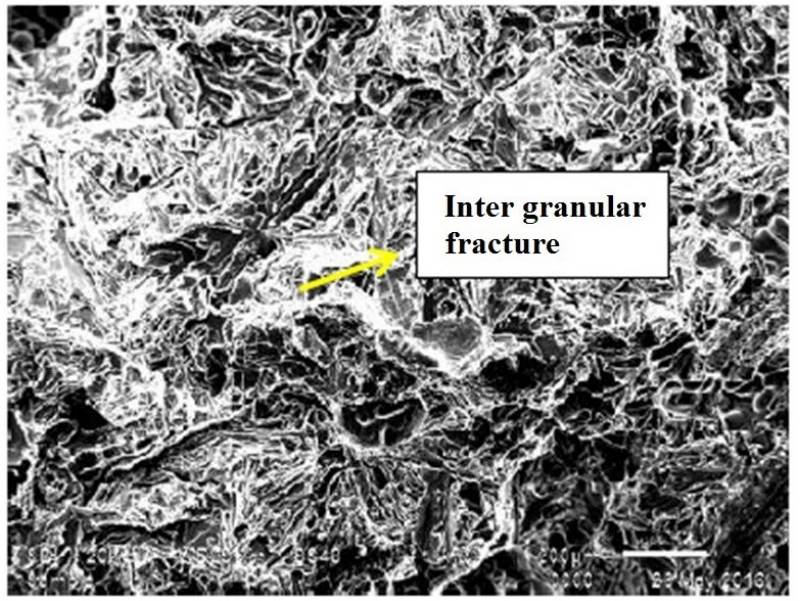

(b)

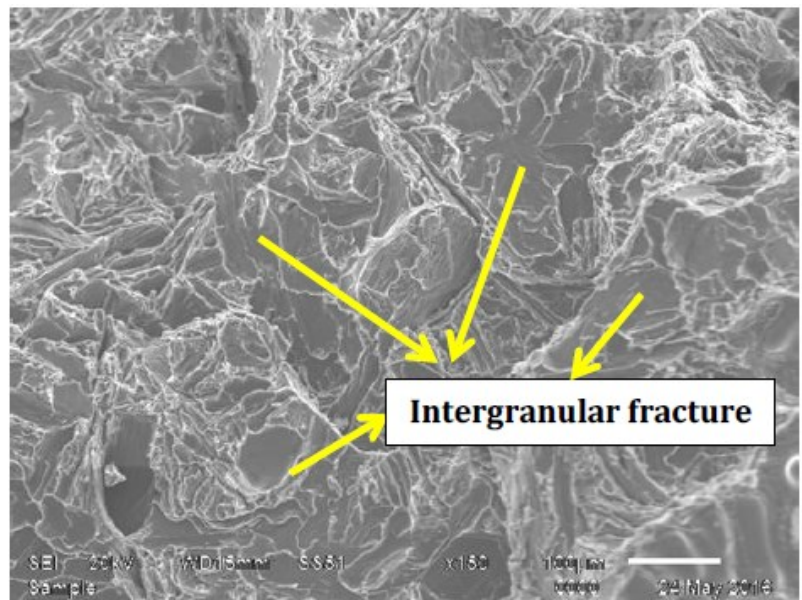

(c)

Fig. 14. SEM micrographs of Impact fractured specimen of A356 alloy castings made by various moulds: (a) $100 \%$ Sand (b) $100 \%$ GBF slag and (c) combinations of these two moulds 

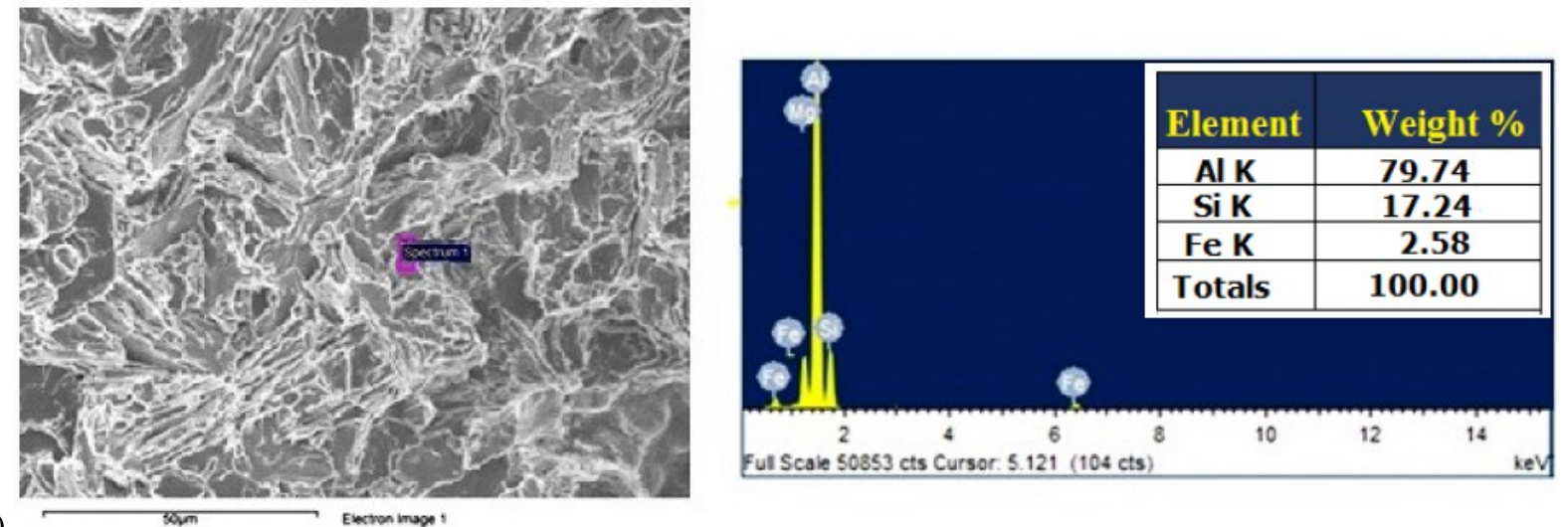

a)
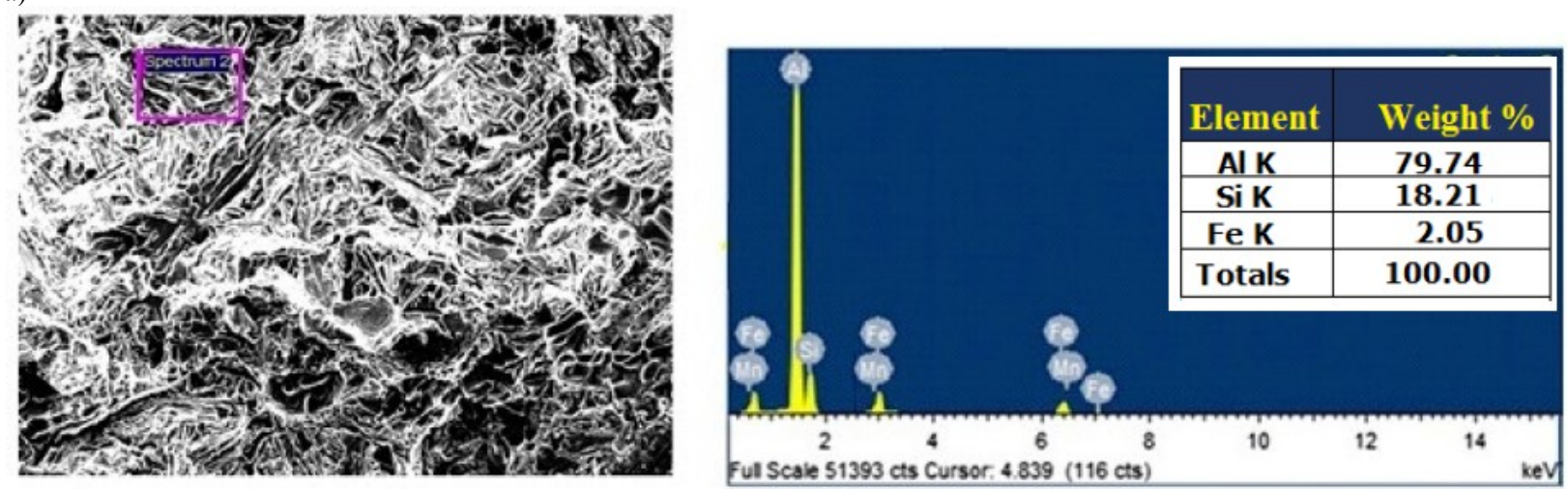

b)

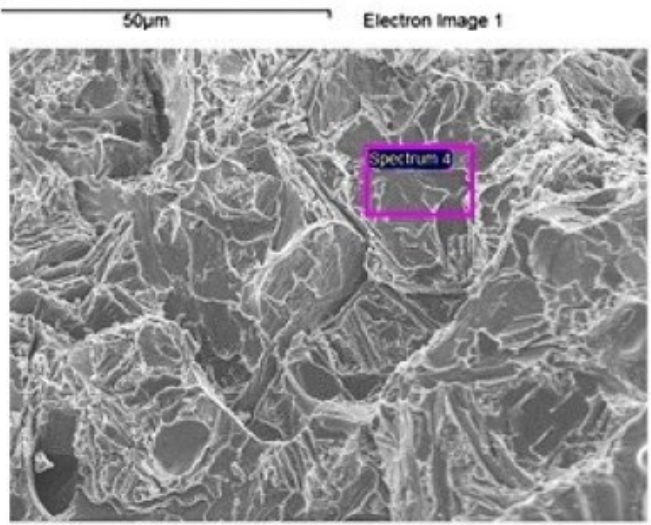

c) sopm

Electron Image 1

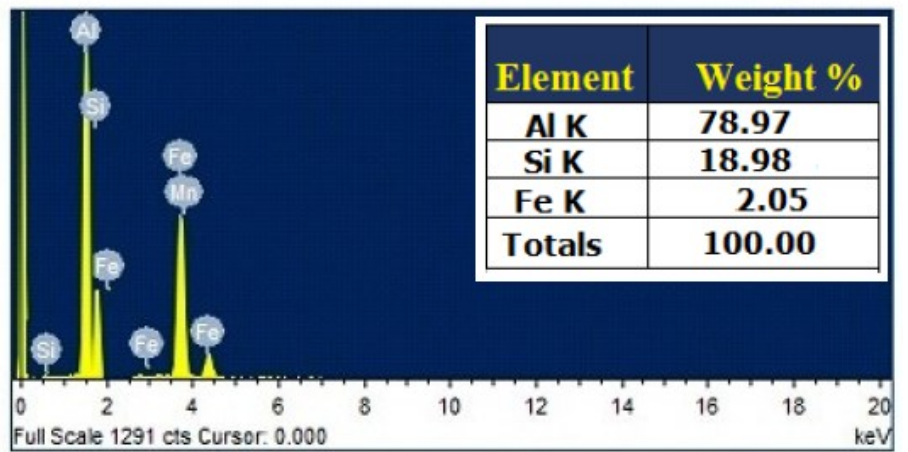

Fig. 15. EDS of the impact fracture surface of A356 alloy made by various moulds: (a) $100 \%$ Sand (b) $100 \%$ GBF Slag (c) combinations of these two moulds

\section{Conclusions}

1. In slag moulds, while casting no burning, neither dripping nor collapse of the mould walls was observed. Also, cast products with good surface finish, no surface defects and without porosity were produced.

2. Faster heat transfer in slag moulds enabled the cast products with fine and refined grain structured than sand mould; hence, lower Secondary Dendrite Arm Spacing (SDAS) values were reported in slag mould castings than sand.
3. Consistent and uniform hardness was observed throughout the cross section of the samples. However, sand mould casting shows lower hardness compared to slag castings. The slag mould castings show higher compression and tensile strengths with slightly improved amount of deformation than the sand moulds.

4. Sand mould castings shows two types of fracture characteristics, namely cleavage pattern with flat surfaces representing $\mathrm{Al}-\mathrm{Si}$ eutectic zone and the areas of broken $\mathrm{Fe}$ rich intermetallic compounds with appear as flower-like 
morphology. In contrast, GBF slag mould castings exhibit majority in dimple fracture morphology with traces of cleavage fracture.

5. Charpy impact fractured surfaces of sand mould castings shows both transgranular and intergranular fracture modes. Only intergranular fracture mode was noticed in both GBF slag and mixed mould castings.

6. Based on these present investigations, GBF Slag can be used as alternative mould materials; and these moulds lead to produce castings with improved surface finish, enhanced metallurgical and mechanical properties while reduced operational costs.

\section{Acknowledgements}

Authors thank the DST -Fly Ash unit, New Delhi, India for their financial support (Grant Ref No: FAU/DST/600(52)/201213). Special thanks to $\mathrm{M} / \mathrm{s}$. Visakhapatnam Steel Plant, Visakhapatnam, India for supply of GBF Slag this study.

\section{References}

[1] Fan Zitian, Huang Naiyu \& Dong Xuanpu, (2004). In house reuse and reclamation of used foundry sands with sodium silicate binder. International Journal of Cast Metals Research. 17, 51-56.

[2] Ahmed, S. \& Ramrattan, S.N. (1990). Comparison of Handling Properties Using $\mathrm{CO}_{2}$ Activated Binder Systems, AFS Transactions. 98, 577-586.

[3] Narasimha Murthy, I. \& Babu Rao J. (2015). Investigations on Physical and Chemical Properties of High Silica Sand, Fe-Cr Slag and Blast Furnace Slag for Foundry Applications. Resource Efficient Waste Management. Nov 2015, 553-561.

[4] Narismha Murthy, I., Arun Babu, N., Babu Rao J. (2015). High carbon Ferro Chrome Slag and GBF Slag - Alternative Mould Material for Foundry Industry $-5^{\text {th }}$ International Conference on Solid Waste Management, ( $5^{\text {th }}$ IconSWM 2015), Bangalore, India, 24 - 27 November, 2015, p. 62.

[5] Adedayo, A.V. \& Aremo B. (2011). Influence of Mould Heat Storage Capacity on Properties of Grey Iron. Journal of Minerals \& Materials Characterization \& Engineering. 10(4), 387-396.

[6] HU Xiaowu, AI Fanrong, \& YAN Hong, (2012). Influences of pouring temperature and cooling rate on microstructure and mechanical properties of casting $\mathrm{Al}-\mathrm{Si}-\mathrm{Cu}$ aluminum alloy, Acta Metall. Sin.(Engl. Lett.). 25(4), 272-278.

[7] Wasiu Ajibola Ayoola, Samson Olurropo Adeosun, Olujide Samuel Sanni, \& Akinlabi Oyetuni (2012). Effect of Casting Mould on Mechanical Properties of 6063 Aluminium alloy, Journal of Engineering Science and Technology. 7(1), 89-96.

[8] Ying-Dong Qu, Mei-Ling Jin, Gang Qin, Rong-De Li, MinQiang Gao, Feng-Shuang Sun, \& Jun-Hua You (2014). Ultra-Long Pore Fabrication Process by Pulling-Casting in Aluminum Alloy. Materials and Manufacturing Processes. 29(10), 1205-1209.
[9] Minghui Ding, Jingtao Song, \& Liu Honghui, (2014). Effect of Pouring Temperature on Typical Structure of Thin-Walled ZL105A Alloy Casting. Materials and Manufacturing Processes. 29(7), 853-863.

[10] Ahmad, H., Naher, S. \& Brabazon, D. (2014). The Effect of Direct Thermal Method, Temperature and Time on Microstructure of a Cast Aluminum Alloy. Materials and Manufacturing Processes. 29(2), 134-139.

[11] Rao A. Shailesh, S Mahantesh. Tattimani, S Shrikantha Rao (2015). Understanding Melt Flow Behavior for Al-Si Alloys Processed Through Vertical Centrifugal Casting. Materials and Manufacturing Processes. 30(11), 1305-1311.

[12] Hsien-Chi Sun, \& Long-Sun Chao, (2009), An Investigation into the Effective Heat Transfer Coefficient in the Casting of Aluminum in a Green-Sand Mold, Materials Transactions. The Japan Institute of Metals. 50(6), 1396-1403.

[13] Mondolfo, L.F. (1943). Metallography of Aluminum Alloys, New York John Wiley \& sons, Inc.

[14] Ye Haizhi (2003). An Overview of the Development of AlSi-Alloy Based Material for Engine Applications. Journal of Materials Engineering and Performance, ASM International. 12(3), 288-297.

[15] Mae, H., Teng, X., Bai, Y. \& Wierzbicki, (2008). Comparison of ductile fracture properties of aluminium castings: sand mold vs. metal mold. Int. Journal of Solids and Structures. 45, 1430-1444.

[16] Casting. ASM Hand book (1992). vol 15, ASM International.

[17] D. Hanumantha Rao., G.R.N Tagore., G Ranga Janardhana (2010). Evolution of Artificial Neural Network (ANN) model for predicting secondary dendrite arm spacing in aluminium alloy casting. J. Braz. Soc. Mech. Sci. \& Eng. 32(3), 276-281.

[18] Kadushnikov, M., Alievskiŭ, V.M., Somina, S.V., Kozerchuk, A.L. \& Petrov, M.S. (2011). Digital microscopy from Nano to macro, using the SIAMS image-analysis system. Journal of Optical Technology. 78(1), 61-65.

[19] Yildirim, M. \& Özyürek, D. (2014). The effects of mould materials on microstructure and mechanical properties of cast A356 alloy. Journal of Advanced Materials and Processing. 2(4), 3-12.

[20] M.N. Shetty, (2013). Dislocations and Mechanical behavior of Materials, Delhi, India, PHI Learning, Pvt. Ltd.

[21] Weng-ming JIANG, Zi-tian FAN, \& De-jun LIU (2012), Microstructure, tensile properties and fractography of A356 alloy under as-cast and T6 obtained with expendable pattern shell casting process. Transaction of nonferrous metals society of china. 22, 7-13.

[22] Wenming Jiang, Zitian Fan, Dejun Liu, Defeng Liao, Xuanpu Dong, \& Xiaoming Zong, (2013). Correlation of microstructure with mechanical properties and fracture behavior of A356-T6 aluminum alloy fabricated by expendable pattern shell casting with vacuum and lowpressure, gravity casting and lost foam casting. Materials Science and Engineering: A. 560, 396-403.

[23] Ji-hua Peng, Xiao-long Tang, Jian-ting HE, \& De-ying XU (2011), Effect of heat treatment on microstructure and Tensile properties of A356 alloys. Transaction of nonferrous metals society of china. 21, 1950-1956. 
[24] Wang, Q.G. (2003). Microstructural Effects on the Tensile and Fracture Behavior of Aluminum Casting Alloys A356/357. Metallurgical and Materials Transactions A. 34 A, 2887-2899.

[25] Guo-hua Zhang, Jian-xin Zhang, LI Bing-chao, \& Wei Cai (2011). Characterization of tensile fracture in heavily alloyed Al-Si piston alloy. Progress in natural science: Materials International. 21, 380-385.

[26] Merlin M., \& Garagnani, G.L. (2009). Mechanical and microstructural characterization of A356 castings realized with full and empty cores. Metallurgical Science and Technology. 127(1), 21-30.

[27] Ceschini, L., Jarfors, A., Al Morri, Al., Morri, An,, Rotundo, F., Seifeddine, S. \& Toschi, S. (2014). High temperature tensile behaviour of the A354 aluminum alloy. Materials Science Forum. 794-796, 443-448.
[28] Casari, D., Merlin, M. \& Garagnani, G.L. (2013). A comparative study on the effects of three commercial Ti-Bbased grain refiners on the impact properties of A356 cast aluminium alloy. Journal of Mater Science. 48, 4365-4377.

[29] Merlin, M., Timelli, G., Bonollo, F. \& Garagnani, G.L. (2009). Impact behaviour of A356 alloy for low-pressure die casting automotive wheels. Journal of Materials Processing Technology. 209(2), 1060-1073.

[30] Alexopoulos, D.N. (2010). Impact properties of the aircraft cast aluminium alloy Al-7Si-0.6Mg (A357). EPJ Web of Conferences. 02002(6), 1-8.

[31] M Amne Elahi, S.G. Shabestari, (2016). Effect of various melt and heat treatment conditions on impact toughness of A356 aluminum alloy. Trans. Nonferrous Met. Soc. China. 26, 956-965. 